from the neighbouring collieries. The coke oven plant is designed to deal with 1,370 tons of coal a day. a complete by-product recovery plant being provided, The two blast furnaces have been entirely reconstructed, the output of each being increased to 3,500 tons of pig iron. The molten iron from the blast furnaces is taken direct to the steel works, but any surplus not required at the moment is diverted to a pig-casting shop. The molten metal is first poured into a 1,400-ton mixer, where it is kept in a molten state until it is required to charge the furnaces. The molten steel is discharged from the furnaces at floor level and is cast into ten-ton ingots.

\section{River Control in Great Britain}

A BROADShEET issued by Political and Economic Planning (PEP) deals with the difficulties which regionalism presents to the efficient operation of specialized and technical services, as exemplified in the control of rivers. Already the Ministry of Health, the Ministry of Agrieulture and Fisheries, the Ministry of Transport, the Electricity Commissioners, the Board of Trade, the Mines Department, the Home Office and the Development Commissioners are concerned with different aspects of water supply and the control of rivers in Great Britain. The Land Drainage Act of 1930 was a consolidating and amending measure based on the recommendations of a Royal Commission and created some forty-nine catchment areas which cover the greater part of England and Wales, but the process of constituting and reorganizing drainage boards within catchment areas is not yet complete. Navigable rivers are controlled mainly by 51 public bodies, and waterways are owned by the railways and 31 other companies.

IN the even more important matter of water supply, there are ot present $\mathbf{7 8 2}$ local authorities and 50 joint authorities supplying, besides $236 \mathrm{com}$ panies and 1,053 private proprietors. To secure further rationalization and conservation of water supplies, nine regional advisory committees have been created, and a sub-committee of the Advisory Water Committee recently recommended that other committees should be created in the Greater Metropolitan Area, South Wales and the North-East. The possibility of damage to mains and reservoirs during air raids makes working agreements even more essential. The control of sewage presents yet another problem calling for co-ordination, while there are nearly fifty fishery boards concerned to prevent pollution of rivers, which may come into conflict with the navigation authorities. Moreover, town and country planning schemes are required to prevent ribbon development along river banks and undue pressure to develop sites. It is suggested that the Thames Conservancy Board, which is both a conservancy and catchment authority and has power over pollution and fisheries, is a model of what is required. How far it would be possible to entrust the general supervision of all water interests to one central department is a matter for discussion.

\section{British Museum (Natural History) : Recent Acquisitions}

The Trustees have purchased for the Department of Mineralogy uncut erystals of topaz, sapphire, and a set of seven rough crystals of ruby from Mogok, while cut stones are represented by a good example of deep lilac-coloured kunzite and a remarkable clear yellow cassiterite, cut from a stone from Uganda. A small diamond of considerable interest in the history of diamond-mining has been presented by Sir Ernest Oppenheimer. It is the first diamond taken from the first of the Kimberley diamond mines-the Jagersfontein-and was found by William Wreford Paddon. Dr. Stanley Smith, University of Bristol, has presented a specimen of natural coke showing columnar structure, from a quarry near Cockfield, County Durham. The coke was formed where a coal seam had been burnt out by a basalt dyke. Miss Beatrice O. Corfe has presented to the Department of Botany more than three hundred paintings of British flowers. The Department already possesses a number of Miss Corfe's paintings which were purchased some years ago. The paintings are artistic and at the same time botanically sound, and a number of them suitably adapted have been reproduced in the Museum series of botanical picture postcards. As a result of a short expedition to St. Lucia undertaken for the Museum by Mr. Harold E. Box, more than three hundred flowering plants and ferns were obtained chiefly from the higher altitudes of the mountains in the interior of the island. Unfortunately, Mr. Box's visit coincided with the almost unprecedented rainfall of November last, and twenty out of twenty-eight days had to be spent in camp or indoors.

\section{Fisheries Research in Hong Kong}

AT the recent meeting of the British Association in Cambridge, the president of Section D (Zoology), in a highly important address, directed attention to the fact that the British Empire as a whole is regrettably deficient in fisheries research and administration. This is especially true of British territories in the Far East. In consequence, highly skilled and intensely industrious Japanese fishermen have in recent years been exploiting practically all the great fishing grounds of the Pacific region and landing large quantities of fish at most of the principal fishmarkets-both British and foreign-along the coasts of China, India, Philippines, Malaya and Dutch East Indies. It is highly gratifying, therefore, to note that the University of Hong Kong recently has published a small handbook ("Common Marine Food Fishes at Hong Kong”. By G. A. C. Herklots and S. Y. Lin. Pp. 75. Hong Kong: G. A. C. Herklots, The University. n.d. n.p.) written in both English and Chinese, describing forty of the commonest food fishes landed at Hong Kong fish-markets. Each fish has been given its scientific name, Chinese name or names, and an English name--in some instances specially coined for this book. This is followed by a brief but useful description accompanied by a blackand-white illustration, with notes on distribution, seasonal abundance, price and food value. At the end of the book are set out twelve Chinese and seventeen European recipes for the cooking of fish dishes. 